\title{
ECLIPTA ALBA (BHRINGRAJ): A PROMISING HEPATOPROTECTIVE AND HAIR GROWTH STIMULATING HERB.
}

\author{
ISHA KUMARI, HEMLATA KAURAV, GITIKA CHAUDHARY*
}

Shuddhi Ayurveda, Jeena Sikho Lifecare Pvt. Ltd. Zirakpur, Punjab, India. Email: shuddhi.research@jeenasikho.co.in

Received: 23 March 2021, Revised and Accepted: 30 April 2021

ABSTRACT

Plants are the primary source of food, shelter, and various remedial approaches. They are being in use for treating various kinds of human ailments across the world since the ancient times. One of such important plants is Eclipta alba hassk (Asteraceae) which is commonly known as Bhringraj and false daisy. This plant is known for its extra-ordinary therapeutic properties. It is one of most widely used plant in traditional systems of medicines such as Ayurvedic, Unani, Sidha, homeopathy, Chinese, and folk. Each part of this medicinal plant contains many important phytochemical constituents such as coumestans, triterpenes, flavonoids, steroids, polypeptides, and saponins. It is majorly used for enhancing the growth, strength, and blackening of hair. It is used as the main ingredient in many hair oils. It significantly treats problems related to hair such as hair fall, dandruff, premature greying, and baldness. E. alba exhibits many other important biological properties such as anticancer, anti-bacterial, anti-viral, anti-stress, and immunomodulatory. Thus, this medicinal plant is playing a vital role in the medical field and cosmetic industry. The present review is a summary of phytomedicinal importance of $E$. alba in Ayurveda as well as folk medicine system.

Keywords: Bhringraj, Rasapanchak, Coumestans, Saponin, Hepatoprotective.

(c) 2021 The Authors. Published by Innovare Academic Sciences Pvt Ltd. This is an open access article under the CC BY license (http://creativecommons.org/ licenses/by/4.0/) DOI: http://dx.doi.org/10.22159/ajpcr.2021v14i7.41569. Journal homepage: https://innovareacademics.in/journals/index.php/ajpcr

\section{INTRODUCTION}

Nature is the primary source of numerous medicines for thousands of years $[1,2]$. Among plants, medicinal plants are of great significance. Medicinal plants are those plants whose one or more than one part possess substances which are medically important and are used for the synthesis of new drugs [3,4]. Kingdom plantae is considered as the treasure house of many important drugs. It has been a culture of using medicinal plants [5]. Initially most of the medicinal preparations were obtained from the plants only either in the simpler form or in the complex form [6]. Drugs derived from plants are named as herbal drugs, botanical drugs, botanicals, phytomedicines, traditional medicines, herbal medicines, traditional Chinese medicines (TCMs), traditional herbal medicinal products, natural health products, or plant food supplements. These phytomedicines have advantages over synthetic drugs such as they are easily available, less expensive, safe, and efficient and have negligible side effects [7-10]. Even most of the modern drugs are derived from the natural sources like plants. As per the data resources, quarter of the medicines used in the present times in industrialized countries has been derived from tropical plants directly or indirectly [11-13]. Medicinal plants have a very rich history of their utilization to treat variety of diseases. The practice of using plants to treat diseases and get relief from physical sufferings is as old as the origin of mankind $[14,15]$. As per the estimated reports of the WHO, in developed nations around $80 \%$ of the total population rely majorly on the phytomedicines for maintaining their health and fulfilling basic requirements [16-19]. India comes under the category of world biodiversity centers which is blessed with the rich medicinal plant history having more than 45,000 diverse species of plants; therefore, it is considered as Botanical garden of the world [20,21]. Indian medicinal plants are used in many traditional systems of medicine such as Ayurveda, Siddha, Unani Folk system, and as well as allopathy [22]. Ayurveda is the most ancient traditional medicine system. There are almost 600 medicinal plants and their formulations are being in use in Ayurvedic practices for the treatment of several diseases [23]. In U.K. around $25 \%$ of population use phytomedicines in their day-today routine. Phytomedicines are used in each and every corner of the world. Medicinal herbs are used for the healing purpose by African population [24]. In Africa, traditional medicines are being in use since 4000 years. These medicines served as the primary health-care system in the absence of modern medicines [25,26]. More than 1000 species of plants are mentioned in the compendium of Materia Medica which is an ancient encyclopedia of TCM [27]. In China, medicinal plants are being in therapeutic use in dietary therapy for numerous years and thus maintaining the health $[28,29]$. As per the reported data, 60 out of 104 global drugs that are used for last 37 years have been derived from the TCM plants [30]. In countries like West Africa modern drugs are not affordable by many people thus people rely on phytomedicines for cure and heal purpose [31]. About $85 \%$ of Swazis and Nigerians use traditional medicine as a health-care system $[32,33]$. Approximately $27 \%$ of South African population uses traditional medicines as its main health care system. Eclipta alba (L.) (Fig. 1) is one of most well-known and valuable medicinal plants in India. It is commonly named as false daisy and Bhringaraj and Karisilakanni. Genus Eclipta originated from the Greek word "Deficient" which means absence of the bristles and awns on the fruits $[34,35]$. E. alba (L.) belongs to the family Asteraceae. This medicinal plant has rich ethnomedicinal history. E. alba and its therapeutic value has also been mentioned in classical text "Bhavaprakash" [36]. In Ayurveda, it is named as "bhringoraaja", in Unani system; it is named as "bhangra" whereas in Siddha it is named as "karissalaankanni" [37]. E. alba is categorized into three categories on the basis of the color of the flowers/fruits which are white-flowering, the yellow-flowering, and the black-fruiting. Each type is found in marshes, rivers, and lakes or on the foothills of the Himalayas in India [33]. This medicinal plant is mostly used in tropical and sub-tropical regions as a traditional medicine. It is also utilized as a functional food [38]. It is a very famous hepatoprotective drug and popularly called as "King of hair" [39]. The extracts of this medicinal herb are used as preventive measure or as an anti-venom against snakebite. It is used to treat issues related to gastro-intestinal tract, respiratory issues, to heal cut and wounds, inflammation, and many more diseases [40-44]. Wedelolactone, demethylwedelolactone, desmethyl-Wedelolactone, furanocoumarins, oleanane and taraxastane glycosides, and 7glucoside are the primary coumestan derivatives present in E. alba [45,46]. Ecliptal, ß-amyrin, luteolin-7-0-glucoside, hentriacontanol, heptacosanol, stigmasterol are other principle phytochemical constituents of E. alba. Each part of this 
medicinal plant is important from medicinal point of view. E. alba is associated with therapeutic properties such as anticancer, antileprotic, analgesic, antioxidant, antimyotoxic, anti-hemorrhagic, antihepatotoxic, antiviral, antibacterial, spasmogenic, hypotensive, and ovicidal. E. alba is known as "King of hair" because it exhibits properties which enhance the growth and blackening of hair $[47,48]$. It is used externally to treat eczema and in athlete foot [49]. It is also used as a treatment of epilepsy [50]. Vernacular names and Taxonomy of E. alba are shown in Tables 1 and 2.

\section{BOTANICAL DESCRIPTION OF E. ALBA (BHRINGRAJ)}

E. alba (L.) is an annual multibranched herbaceous plant that reaches up to the height of $30-50 \mathrm{~cm}$. The form of this plant may be erect or prostrate. The plant is covered with hair of white color. The hair is present on both the surfaces of leaves. The stem is of red color. There is presence of simple, sessile, and lanceolate leaves which are of length 4-10 cm, breadth $0.8-2 \mathrm{~cm}$, and tallness $90 \mathrm{~cm}$ with slender. The leaves

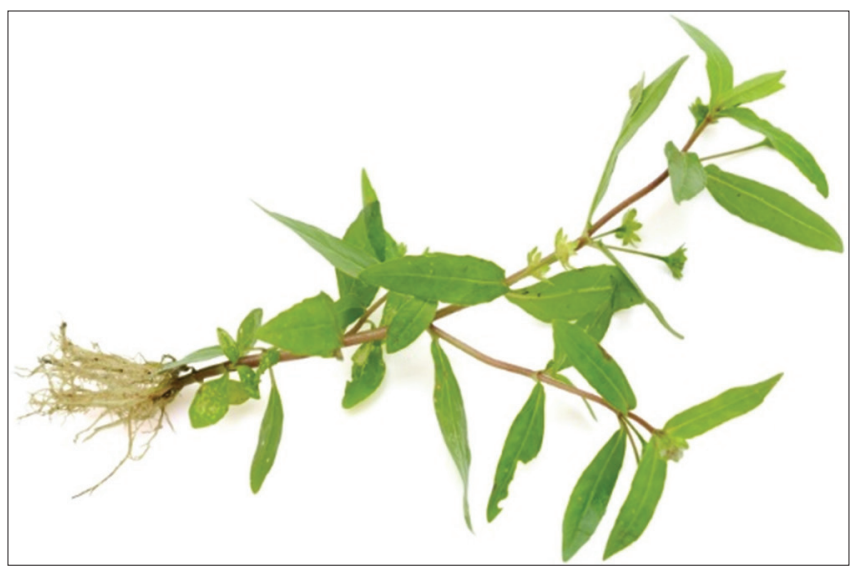

Fig. 1: Eclipta alba (Bhringraj)

Table 1: Vernacular names of Eclipta alba (Bhringraj) [51]

\begin{tabular}{ll}
\hline English & False daisy \\
\hline Sanskrit & Bhrungaraj, Kesharaj, Markava, Kesharanjana, Kesharaj \\
Hindi & Bhangara, Bhangarayya \\
Punjabi & Bhangara, dodhak, Babri \\
Marathi & Maka \\
Gujarat & Bhangaro \\
Bengali & Kesuriya, Kesuti \\
Tamil & Kaikeshi \\
Telugu & Galagara, Gunta, Galijaeru \\
Malyalam & Cajenneam,Kanni \\
Konkani & Mako, Kajalamavu \\
Asamese & Kehraj \\
Arabic & Kadim-ul-bint, Radim-el-bint \\
\hline
\end{tabular}

Table 2: Taxonomy of Eclipta alba (Bhringraj) [52]

\begin{tabular}{ll}
\hline Kingdom & Plantae \\
\hline Subkingdom & Viridaeplantae \\
Infrakingdom & Streptophyta \\
Division & Tracheophyta \\
Subdivision & Spermatophytina \\
Infradivision & Angiospermae \\
Class & Magnoliopsida \\
Superorder & Asteranae \\
Order & Asterales \\
Family & Asteraceae \\
Genus & Eclipta \\
Species & alba \\
Common name & False Lily, Bhringraj \\
\hline
\end{tabular}

are present in opposite manner which are attached to the stem without the presence of petiole. At the lower nodes rooting is present. The floral heads are solitary and white whose diameter is $6-8 \mathrm{~mm}$. Flowers are narrowly winged. The plant has well developed root system. Grey cylindrical roots are present there. The plant is covered with flowers throughout the year. The fruiting period of E. alba is from September to October [53-55].

\section{GEOGRAPHICAL DISTRIBUTION OF E. ALBA (BHRINGRAJ)}

It is found as a weed in tropical and subtropical regions of the world such as South America, Asia, and Africa at an altitude of up to $2000 \mathrm{~m}$. It is found throughout India, China, Thailand, and Brazil, Taiwan, Indonesia, Japan, the Philippines, Bangladesh, and United States. In India, it is mainly found in states Assam, Bihar, Uttar Pradesh, and Manipur [56-60].

\section{PHYTOCHEMISTRY OF E. ALBA (BHRINGRAJ)}

E. alba (Bhringraj) contains wide range of diverse phytochemical constituents which include coumestans, alkaloids, flavonoids, glycosides, polyacetylenes, and triterpenoids, phenolic acids, saponins, sterol, sesquiterpene lactones, proteins, amino acids, carbohydrates, and many more [61-65]. Some major phytochemicals are shown in (Fig. 2).

\section{Coumestans}

Coumestans are the main active phytochemical constituents of E. alba which are the derivatives of coumarin. Wedelolactone, demethylwedelolactone, demethylwedelolactone-7-glucoside, isodemethylewedelol actone, and strychnolactone are the main coumestans present in the whole plant especially in the leaves. These are believed to be associated with anti-cancer properties [66-70].

\section{Alkaloids}

The major alkaloids present in E. alba leaves are (20S) (25S)- 22,26-imino-cholesta-5,22(N)-dien-3 $\beta$-ol (verazine, 3). Other novel alkaloids reported are 20-epi-3- dehydroxy-3-oxo5,6-dihydro- 4,5 dehydroverazine (1), ecliptalbine [(20R)-20pyridyl-cholesta-5-ene-3 $\beta, 23$-diol] (4), (20R)-4 $\beta$-hydroxyverazine (5), 4 $\beta$-hydroxyverazine (6), (20R)-25 $\beta$-hydroxyverazine (7), $25 \beta$ hydroxyverazine and (8), Ecliptalbine (4). While methanolic extract of the plant contains alkaoilds such as verazine, 20-epi3-dehydroxy3-oxo-5, 6-dihydro-4, 5- dehydroverazine ecliptalbine, (20R)-4shydroxyverazine, 4shydroxyverazine, (20R) 25s-hydroxyverazine, and 25 shydroxyverazine. Some other reported alkaloids are ecliptine, nicotine, verazine, and dehydroverazine ecliptalbine [71].

\section{Saponin}

Saponins are mainly associated with the cytotoxic activity. Eclalbatin, alpha-amyrin, ursolic acid, and oleanolic are novel triterpene saponin which has been isolated from the whole plant of E. alba [72-74]. Eclalbatin, dasyscyphin $\mathrm{C}$ is present in the roots which are associated with the properties such as anticancer, antiviral, and antioxidant activity [75].

\section{Sterols}

Stigmasterol, daucosterol, stigmasterol-3-0-glucoside, phytosterol, and $\beta$-glucoside of phytosterol are the major sterols present in E. alba seed $[76,77]$. Stigmasterol is an important sterol which is involved in the process of synthesis of major reproductive hormones like progesterone, androgens, estrogens, and corticoids [78].

\section{Flavonoids}

Apigenin, luteolin and luteolin-7-glucoside, and orobol are the main flavonoids present in E. alba. Apigenin and luteolin are associated with the anti-cancer properties [64]

\section{Terpenoids and their glycosides}

Eclalbasaponins VII-X (taraxastane triterpene glycosides), eclalbasaponins I-VI (oleanane triterpene glycosides), eclalbasaponins 


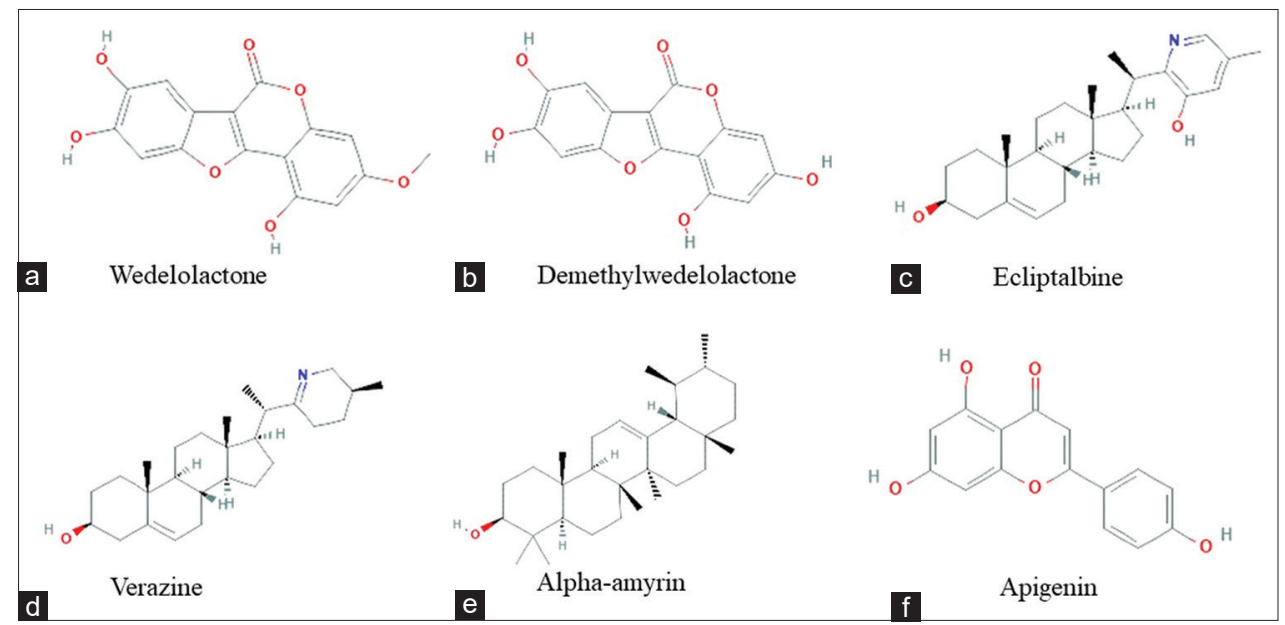

Fig. 2: (a-f) Chemical structures of some of phytochemicals of Eclipta alba

I-VI (triterpene glycosides), ecliptasaponins C and D (triterpenoid glucosides), eclalbatin, $\alpha$-amyrin, $\beta$-amyrin, oleanolic acid, ursolic acid (triterpenoids), wedelic acid are the main terpenoids, and their glycosides present in E. alba. Oleanolic acid, eclalbatin, and $\alpha$-amyrin, are present in the whole plant [79-82]

\section{Phenolic acid}

Protocatechuic acid and 4-hydroxy benzoic acid are the phenolic acid extracted from the E. alba.Sesquiterpene lactones $E$. alba consists of 5-hydroxymethyl-(2,2':5',2")-terthienyl tiglate, 5-hydroxymethyl$\left(2,2^{\prime}: 5^{\prime}, 2^{\prime \prime}\right)$-terthienyl agelate, 5-hydroxymethyl-(2,2':5',2")-terthienyl acetate as its main Sesquiterpene lactone content.

\section{Polypeptides}

The main polypeptides present in E. alba are cystine, glutamic acid, phenyl alanine, tyrosine and methionine.

\section{Volatile oil}

Heptadecane, 6,10,14-trimethyl-2-pentadecanone, n-hexadecanoic acid, pentadecane, eudesma-4(14),11-diene, phytol, octadec-9-enoic ecid, 1,2-benzenediacarboxylic acid diisooctyl ester, (Z,Z)-9,12octadecadienoic acid, (Z)-7,11-dimethyl-3-methylene-1,6,10dodecatriene, (Z,Z,Z)-nt [83].

\section{TRADITIONAL AND MODERN VIEW OF E. ALBA (BHRINGRAJA)}

\section{Ayurvedic view}

E. alba is called as Bhringaraja in Ayurveda. It is one of the most valuable plants in Ayurveda. This magical herb is associated with many biological properties which are being used in many Ayurvedic practices for the treatment of various human ailments. It significantly works on Pitta dosha (Fire and water component of the body) and Vatta dosha (air and space components of the body). It acts aa a rasayana. The extract obtained from the leaves is used as liver tonic, rejuvenative and beneficial for hair, eyes, edema, and phlegm [84]. It is mentioned in Dhanvantari Nighantu, Raj Nighantu, Kaiyyadev Nighantu for its use in pandu, shotha and kamala [85-87]. Rasapanchak of E. alba (Bhringraja) as per Ayurveda is shown in Table 3.

Table 3: Rasapanchak of Eclipta alba (Bhringraja) as per Ayurveda [88]

\begin{tabular}{ll}
\hline Sanskrit/English & Sanskrit/English \\
\hline Virya/Potency & Ushna/Hot \\
Vipak/Metabolic property & Kattu/Pungent \\
Guna/Physical property & Laghu/Light, Ruksha/Rough \\
Guna/Taste & Kattu/Pungent, Tikat/Bitter \\
\hline
\end{tabular}

Properties and uses of E. alba (Bhringraja) $[89,90]$ Sansthanic Karm-wahaya

It is topically used in cuts, wounds, and inflammation/swelling. It reduces headache when its oil is applied on head. It is used as eye/ear drop to reduce pain. It is also used in elephantiasis. It is very good for hair as it helps in growth, strengthening and blackening of hair. It is used in hair disorders such as premature greying, dandruff, hair fall, and baldness.

Abhyantar-nadi sansthan

It is used as pain killer.

Netra

It is beneficial for eyes.

\section{Pachansansthan}

It improves digestion and enhances appetite. It is good for liver. It helps in digestion of "ama" which means toxins and undigested food. It also acts as an anthelminthic. It is used in conditions such as anorexia, hepatomegaly, splenomegaly, jaundice, piles, and abdominal pain.

Rakatwahsansthan/Twacha

It helps in blood augmentation. It used in treating anemia. It induces sweating and helps to fight against skin disorders. It used in treatment of leprosy, psoriasis, eczema, and utricaria.

\section{Swasansansthan}

It has mucolytic property. It is used in cough and cold conditions.

\section{Mootrawahsansthan}

It has diuretic properties. It is used as a cure in burning micturition.

Prajnansansthan

It has aphrodisiac property.

\section{Satmikaran}

It enhances body strength.

\section{Tapkram}

Due to its sweat inducing and ama pachna property it acts as an antipyretic agent.

Some Ayurvedic formulations of E. alba (Bhringraja) [91-94]

Bhringraja is used in many Ayurvedic formulations. For example, 
Bhringraja taila is used for Khalitya (Hair fall or loss of hair). Another formulation of yakrit plihantak churna is used as an hepatoprotective. An important Ayurvedic cosmetological formulation of E. alba along with Vitex negundo, Sphaeranthus indicus and Carum copticum is used as a rejuvenator in the treatment of Kayakalpa.

\section{Folk view}

E. alba (Bhringraja) is an important medicinal herb with rich history of its utilization in various folk systems around the world. It is used to treat numerous diseases. For instance, in Thailand, people use E. alba leaves against skin related problems and hair fall. They use stem to treat tuberculosis, asthma and as a blood tonic while E. alba roots exhibit antibacterial properties [95]. In Egypt, people administer plant juice to blacken the hair and beard [96]. In Philippines, people use this plant for hemoptysis and hematemesis. It is used in tea for treating sprains, furuncle and dermatitis. Dried for the herb is also use against dysentery and heamturia urine [97]. It is used as an emetic and purgative agent and in the treatment of cuts and wounds. People also use it in the treatment of jaundice in Eastern Nepal $[98,99]$. In many areas of India, leaf extract along with cow milk is used against the weakness of vision whereas leaves are also used to reduce wrinkles and heal wounds, palpitation, pimples, premature greying of hair, gingivitis, and alopecia. Whole plant is consumed in treating diarrhea and dysentery, fever, general weakness, jaundice, liver related problems, loss of appetite, and edema, whereas root extract is used against hemorrhoids [100]. In Himachal Pradesh India, people use leaf decoction of E. alba against headache. The extract obtained from the leaves is used against head lice, cold, and asthma [101]. E. alba is a common remedy for the upper respiratory infections and eye/ear infections in children. Bhringraj oil is used all over the India for good hair [102]. In Punjab, Pakistan leaves, roots, and flowers of $E$. alba are prescribed by herbal healers as a cure for liver disorders, hepatic, and spleen ailments. Leaves are used to enhance the digestion and appetite. The whole plant is used as hair tonic, whereas leaves are used to treat athlete's foot disease [103,104]. In Bahawalnagar District, Punjab, Pakistan, people use to chew E. alba leaves to improve their eye health and they treat hypertension using the extract of this plant [105]. In Bahawalpur, Pakistan, this plant is used as a blood purifier and hair tonic. It is also used against leprosy, itching, earache, jaundice, fevers and bleeding disorder, toothache and gum complaints, nausea, and vomiting [106]. In Odisha, India, leaves are used as an antibacterial agent [107]. The juice of E. alba is useful for the expulsion of worms in infants. Manipuri tribes use stem decoction of this plant against liver enlargement while use extracts of leaves in cough and fever. Toto tribe of India uses it as an antidote against scorpion sting. Some communities of Odisha use it as remedy for itching, conjunctivitis and other eye problems. Tribal Societies of Anaikatty Hills, Tamil Nadu, consumes this plant against antifertility, antidote to snake bite, fever, and headache. It is used against toothache, headache, gland swelling, and elephantiasis by people of Sagar tribes, Madhya Pradesh. Asthma, bronchitis, and leukoderma are treated by consumption this plant by tribal Societies of Saurashtra, Gujarat [108]. In Chandauli District of Uttar Pradesh, people use leaves of $E$. alba against dandruff along with seeds of Foeniculum vulgare [109]. In Javadhu Hills Tamil Nadu, E. alba leaves are used for treating diabetes [110]. Gujjars of Rajaji Tiger Reserve, Uttarakhand, treat liver problems with the leaves of this plant [111]. In some areas of Tamil Nadu, people use the paste made up of leaves of $E$. alba to prevent dandruff and to enhance the hair growth [112]. In some villages of Dakshin Dinajpur District, West Bengal, people use leaf and seed of this plant to treat problems related to stomach and liver, inflammation, digestion, and use it as a hair tonic [113]. In West Nimar district, Madhya Pradesh, people use oil extracted from the seeds of E. alba to enhance the hair growth [114]. In areas around the Dandeli Wild Life Sanctuary, people treat warts and leprosy by applying the $E$. alba leaf juice [115]. People of Warangal district of Andhra Pradesh, use this plant to avoid hair fall and provide strength to hair and to increase the appetite [116]. The people of Nandurbar tribe of Maharashtra use this plant as a remedy for menorrhagia [117]. The tribal people of Peth and Trimbakeshwar of Nashik District, Maharashtra, the leaves of $E$. alba are used for treating the injuries caused by mud [118]. In Chennai, people use whole plant as a liver tonic. Leaf juice along with honey is used to treat cough and watery nose in children. Furthermore, the leaves juice is used for hair growth [119]. In Karnataka, this plant is used as an antidote for scorpion bite while the paste made up of this plant is used to blacken and strengthen the hair [120]. In Chittagong Hill Tracts, Bangladesh, people use paste made up of stem, and leaves of E. alba against skin problems [121]. In Koikuri, Dinajpur, this plant is used to heal wounds and as a remedy for skin diseases [122]. In West Singhbhum districts of Jharkhand, people eat E. alba leaves used as a leafy vegetable as a cure to anemia [123]. The plant is administered as nasal or eye drop to get relief from pain and chronic headache in Bayelsa state of Nigeria [124].

\section{Modern view}

In the modern era people are showing great interest in herbal medicines because these have several advantages over the modern synthetic drugs. The demand of herbal drugs in the market is increasing rapidly due to which the chances of their adulteration/contamination have also increased $[125,126]$. There are several factors which promote the degradation of the herbal products such as misidentification of species or plant parts, intentional adulteration, and contamination. Due to all these factors the quality and safety of herbal drugs is in question [127]. There are reported cases of misidentification of herbal plants that might happen due to similarities of morphology of the plants and sometimes due to conflict in the common as well scientific names of the plants. This is one of the primary reasons that lead to the degrading of the herbal products [128]. Another major factor of degradation of herbal products is intentional adulteration which is done in many ways such as by inducing either orthodox drugs or by substituting products of inferior quality or by introducing foreign particles or contaminants like sand, metals, soil etc. The main purpose behind intentional adulteration is to derive maximum profit [129-131]. Most commonly used contaminants in herbal products are heavy metals like mercury, arsenic, and lead, cadmium, copper and thallium. Other contaminants used are pesticides, microbes, and mycotoxins [132-138]. The most common forms of herbal drugs available in the market are powders, capsules, and extracts. Adulterants are often induced before processing stage or during the processing of herbal drugs. Proper quality analysis standardization at these stages are required to avoid health risks [139141]. Standardization of herbal drugs confirms the accurate quantity, quality and associated therapeutic properties with dosage [142]. Techniques like standard DNA barcode have proved to be important in detecting species misidentification [143].

\section{PHARMACOLOGICAL AND THERAPEUTIC USES OF E. ALBA (BHRINGRAJA)}

E. alba (Bhringraja) has variety of phytochemical constituents present in it which exhibit various therapeutic properties. Some of its reported therapeutic uses are summarized below.

\section{Hepatoprotectivity}

Singh et al. conducted a study on rats and mice models in which lung injury was induced artificially by carbon tetrachloride. It was found that alcoholic extract of E. alba (Bhringraja) exhibit hepatoprotective activity at a dosage of $62.5-500.0 \mathrm{mg} / \mathrm{kg}$ p.o. Extract restored all the changes induced by carbon tetrachloride [144]. The experimental study conducted by Naik et al., on albino rat models treated with high fatty diet to investigate the hepatoprotective activity of E. alba (Bhringraja) demonstrated that phytochemical constituents such as Wedelolactone, demethylwedelolactone, and saponins are associated with hepatoprotectivity. It was found that these phytochemicals significantly reduced the fat deposition, mononuclear infiltration, and necrotic foci. Regeneration of hepatocytes in the liver was also stimulated by these phytochemical constituents [145]. This activity was also investigated by Ahirwar and Saxena, on albino rat models. Models were artificially induced with hepatotoxicity by carbon tetrachloride. It was found that isolated fraction of $E$. alba had significant hepatoprotective potential at dosage of $200 \mathrm{mg} / \mathrm{kg}$ body weight. The protein levels were 
restored after the treatment with E. alba extract. [146]. This activity was also supported by a comparative study conducted by Kumar et al., on albino rat models. In this study paracetamol was used to induce hepatotoxicity in the models. Alcoholic and aqueous extracts were comparatively investigated. It was found that alcoholic extract of $E$. alba has more potent hepatoprotective activity [147]. Indhuleka and Jeyaraj performed an investigative study on animal models to find out the hepatoprotective nature of E. alba. Models were induced with hepatotoxicity by paracetamol. Study revealed that E. alba has potent hepatoprotective activity [148].

\section{Hair growth}

Begum et al. conducted a study on nude mice to evaluate the hair growth promoting activity of E. alba. Petroleum ether extract (PEE) along with other solvent fractions of E. alba was topically applied on the backs of nude mice. Prominent follicular hypertrophy was observed after the treatment with PEE. In the basal epidermal and matrix cells, follicular keratinocytes number was increased. These changes support E. alba use in the growth of hair [42]. Another study conducted by Begum et al., supported the use of E. alba for hair growth. The study was conducted on nude mice models which were genetically suffering from hair loss due to abnormal keratinization. It was revealed from the study that topical application of methanolic extract of E. alba had significant impact on the hair growth of mice models. It was observed that hair follicle number had increased after the treatment which shows that $E$. alba is a brilliant hair growth promoter [149].

\section{Anti-cancer}

An in vitro study was conducted by Chaudhary et al., to evaluate the anti-cancer potential of E. alba. The model systems used for the study were Human liver cancer cell line (HepG2), C6 glioma and A498 cell lines. It was found that hydroalcoholic extract of this plant caused inhibition of cell proliferation [150].

\section{Antibacterial}

An in vitro study conducted by Gurrapu and Mamidala, on Escherichia coli, Pseudomonas aeruginosa, Shigella boydii, Staphylococcus aureus, and Streptococcus faecalis demonstrated that E. alba can be used as a good antimicrobial agent. It was found that alkaloids extracted from E. alba has inhibitory against these bacterial strains [151]. Karthikumar et al. evaluated the anti-bacterial and anti-oxidant potential of E. alba on bacterail species E. coli, Klebsiella pneumoniae, Shigella dysenteriae, Salmonella typhi, P. aeruginosa, Bacillus subtilis, and S. aureus. Ethanol and ethyl acetate extracts were found to be significant antibacterial agents. Ferric thiocynate method was employed for the evaluation of anti-oxidant potential. Hexane, ethyl acetate, ethanol, and water extract showed anti-oxidant activity at various concentrations $(50,100,250$, and 500 in $\mu \mathrm{g} / \mathrm{mL}$ ) while aqueous extract showed significantly less activity than the other extracts [152].

\section{Anti-viral}

A study conducted by Manvar et al., against Hepatitis C virus (HCV) showed that E. alba extract had significant inhibitory actions against RNA dependent RNA polymerase activity of HCV replicas in vitro whereas it caused inhibition of HCV replication in cell-culture system which showed its anti-viral potential [153].

\section{Memory enhancer}

Banji et al. examined the memory enhancing activity of $E$. alba. The suspension of E. alba extract in distilled water was administered to rat models. They evaluated the transfer latency of models on an elevated plus maze. The study revealed that $E$. alba is associated with memory enhancing activities [154].

\section{Immunomodulatory}

Syed et al. evaluated the immunomodulatory behavior of E. alba in an in-vitro study. It was found that coumestans such as Wedelolactone and demethylwedelolactone had inhibitory actions against trypsin which supports its use as an immunomodulatory agent [155]

\section{Anti-stress}

Chanu et al. studied anti-stress property of E. alba in Labeo calbasu fingerlings in stress was induced by acid. It was observed that ethanolic extract of the plant exhibited anti-stress activity by restoring the levels of stress hormones - serum cortisol, glucose, alanine amino transferase, aspartate amino transferase - and enzymes - lactate dehydrogenase, malate dehydrogenase, ATPase, superoxide dismutase, and catalase which showed its anti-stress activity [156].

\section{CONCLUSION}

E. alba (Bhringraj) is a wonder herb which is most commonly used in traditional systems of medicine for treating numerous human ailments. It is widely used for its extra-ordinary property of enhancing the hair growth and provides strength to hair. It possesses wide range of phytochemical constituents such as coumestans, saponins, and alkaloids which exhibit significant biological properties such as hepatoprotectivity, antibacterial, anti-viral, anti-stress, and immunomodulatory. It is used in almost each culture and tribe of the world. It is also used as leafy vegetable in some cultures. In Ayurveda, it is used against diseases such as elephantiasis, anorexia, leprosy, eczema, psoriasis, jaundice, piles, cough, col, and splenomegaly. This small medicinal herb with multiple therapeutic applications can be a promising and reliable source of new drugs in future.

\section{AUTHOR CONTRIBUTION}

We declare that this work was done by the authors named in this article and all liabilities pertaining to claims relating to the content of this article will be borne by the authors.

Dr. Gitika Chaudhary drafted the article and contributed in writing Ayurvedic view of the article. Dr. Hemlata Kaurav contributed in drafting and writing pharmacological portion of plant.

Isha Kumari contributed in data collection and writing the paper.

\section{CONFLICT OF INTEREST}

No potential conflict of interest was reported by the authors.

\section{AUTHOR FUNDING}

No any funding for this article writing.

\section{REFERENCES}

1. Nair R, Kalariya T, Chanda S. Antibacterial activity of some selected Indian medicinal flora. Turk J Biol 2005;29:41-7.

2. Ghorbani A. Studies on pharmaceutical ethnobotany in the region of Turkmen Sahra, north of Iran: (Part 1): General results. J Ethnopharmacol 2005;102:58-68.

3. Chukwuma EC, Soladoye MO, Feyisola RT. Traditional medicine and the future of medicinal Plants in Nigeria. J Med Plants Stud 2015;3:23-9.

4. Lifongo LL, Simoben CV, Ntie-Kang F, Babiaka SB, Judson PN. A bioactivity versus ethnobotanical survey of medicinal plants from Nigeria, West Africa. Nat Prod Bioprospect 2014;4:1-9.

5. Akintonwa A, Awodele O, Afolayan G, Coker HA. Mutagenic screening of some commonly used medicinal plants in Nigeria. J Ethnopharmacol 2009;125:461-70.

6. Ayyanar M, Ignacimuthu S. Ethnobotanical survey of medicinal plants commonly used by Kani tribals in Tirunelveli hills of Western Ghats, India. J Ethnopharmacol 2011;134:851-64.

7. Yadav RN, Agarwala M. Phytochemical analysis of some medicinal plants. J Phytol 2011;3:10-4.

8. Simmler C, Graham JG, Chen SN, Pauli GF. Integrated analytical assets aid botanical authenticity and adulteration management. Fitoterapia 2018;129:401-14.

9. Ichim MC. The DNA-based authentication of commercial herbal products reveals their globally widespread adulteration. Front Pharmacol 2019;10:1227.

10. Nagabhushan RK, Raveesha A. Ethnobotanical survey and scientific validation of medicinal plants used in the treatment of fungal infections in Agumbe region of Western Ghats, India. Int J Pharm Pharm Sci 
2015;7:273-7.

11. Yorek N, Aydin H, Ugulu I, Dogan Y. An investigation on students' perceptions of biodiversity. Online Submission 2008;7:175-84.

12. Ateș DA, Turgay Ö. Antimicrobial activities of various medicinal and commercial plant extracts. Turk J Biol 2003;27:157-62.

13. Newman DJ, Cragg GM, Snader KM. The influence of natural products upon drug discovery. Nat Prod Rep 2000;17:215-34.

14. Abu-Shanab B, Adwan GM, Abu-Safiya D, Jarrar N, Adwan K. Antibacterial activities of some plant extracts utilized in popular medicine in Palestine. Turk J Biol 2005;28:99-102.

15. Hill AF. Economic botany. In: A Textbook of Useful Plants and Plant Products Economic Botany. London: McGraw-Hill Publishing Co. Ltd.; 1937.

16. Foster BC, Arnason JT, Briggs CJ. Natural health products and drug disposition. Annu Rev Pharmacol Toxicol 2005;45:203-26.

17. Akinyemi B. Recent concept in plaque formation. J Clin Pathol 2000;30:13-6

18. Calixto JB. Twenty-five years of research on medicinal plants in Latin America: A personal view. J Ethnopharmacol 2005;100:131-4

19. Sahito SR, Memon MA, Kazi TG, Kazi GH, Jakhrani MA, Haque QU, et al. Evaluation of mineral contents in medicinal plant Azadirachta indica (Neem). J Chem Soc Pak 2003;25:139-43.

20. Sukumaran S, Raj AD. Medicinal plants of sacred groves in Kanyakumari district Southern Western Ghats. Vol. 9. Council of Scientific and Industrial Research; 2010. p. 294-9.

21. Abd El-Ghani MM. Traditional medicinal plants of Nigeria: An overview. Agric Biol J North Am 2016;7:220-47.

22. Verma S, Singh SP. Current and future status of herbal medicines. Vet World 2008;1:347.

23. Singh AP. Promising phytochemicals from Indian medicinal plants. Ethnobot Leaf 2005;2005:18.

24. Bussmann RW, Gilbreath GG, Solio J, Lutura M, Lutuluo R, Kunguru K, et al. Plant use of the Maasai of Sekenani Valley, Maasai Mara, Kenya. J Ethnobiol Ethnomed 2006;2:1-7.

25. Okoli RI, Aigbe O, Ohaju-Obodo JO, Mensah JK. Medicinal herbs used for managing some common ailments among Esan people of Edo State, Nigeria. Pak J Nutr 2007;6:490-6.

26. Moerman DE. Medicinal Plants of Native America. Ann Arbor: Museum of Anthropology, University of Michigan Museum; 1986.

27. Yang L, Yang C, Li C, Zhao Q, Liu L, Fang X, et al. Recent advances in biosynthesis of bioactive compounds in traditional Chinese medicinal plants. Sci Bull 2016;61:3-17.

28. Gan RY, Kuang L, Xu XR, Zhang Y, Xia EQ, Song FL, et al. Screening of natural antioxidants from traditional Chinese medicinal plants associated with treatment of rheumatic disease. Molecules 2010;15:5988-97.

29. Zuo GY, Zhang XJ, Yang CX, Han J, Wang GC, Bian ZQ. Evaluation of traditional Chinese medicinal plants for anti-MRSA activity with reference to the treatment record of infectious diseases. Molecules 2012;17:2955-67.

30. Gen XP. Medicinal Plants: The Chinese Approach. Vol. 7. Geneva: World Health Organization Forum; 1986. p. 84-5.

31. Hostettmann K, Marston A. Twenty years of research into medicinal plants: Results and perspectives. Phytochem Rev 2002;1:275-85.

32. Green EC, Makhubu L. Traditional healers in Swaziland: Toward improved cooperation between the traditional and modern health sectors. Soc Sci Med 1984;18:1071-9.

33. Chokotia LS, Vashistha P, Sironiya R, Matoli H. Pharmacological activities of Eclipta alba (L.). Int J Res Dev Pharm Life Sci 2013;2:499502.

34. Puri HS. Rasayana: Ayurvedic herbs for longevity and rejuvenation: Volume 2 of traditional herbal medicines for modern times. J Altern Complement Med 2003;2:331-2.

35. Dalal S, Rana S, Sastry K, Kataria S. The Wealth of India. Vol. 3. New Delhi: Raw Materials, Council of Scientific and Industrial Research; 1952. p. 127-8.

36. Anil Kumar Y, Ravi Kumar K, Sirisha Y, Gopikrishna B, Yashita raga S. In vitro anti cancer activity of ethanolic extract of Eclipta alba (L.). Am J Pharm Health Res 2018;6:79-87.

37. Jahan R, Al-Nahain A, Majumder S, Rahmatullah M. Ethnopharmacological significance of Eclipta alba (L.) hassk. (Asteraceae). Int Sch Res Notices 2014;2014:1-22.

38. UdayashankarAC, Nandhini M, Rajini SB, Prakash HS. Pharmacological significance of medicinal herb Eclipta alba 1 . a review. Int J Pharm Sci Res 2019;10:3592-606.

39. Kirtikar KR, Basu BD. Indian Medicinal Plants. Vol. 3. Dehardun: International Book Distributors; 1999. p. 1616-7.
40. Saxena AK, Singh B, Anand KK. Hepatoprotective effects of Eclipta alba on subcellular levels in rats. J Ethnopharmacol 1993;40:155-61.

41. Pithayanukul P, Laovachirasuwan S, Bavovada R, Pakmanee N, Suttisri R. Anti-venom potential of butanolic extract of Eclipta prostrata against Malayan pit viper venom. J Ethnopharmacol 2004;90:347-52.

42. Begum S, Lee MR, Gu LJ, Hossain J, Sung CK. Exogenous stimulation with Eclipta alba promotes hair matrix keratinocyte proliferation and downregulates TGF- $\beta 1$ expression in nude mice. Int J Mol Med 2015;35:496-502.

43. Neamsuvan O, Ruangrit T. A survey of herbal weeds that are used to treat gastrointestinal disorders from Southern Thailand: Krabi and Songkhla Provinces. J Ethnopharmacol 2017;209:318-27.

44. Tambe R, Patil A, Jain P, Sancheti J, Somani G, Sathaye S. Assessment of luteolin isolated from Eclipta alba leaves in animal models of epilepsy. Pharm Biol 2017;55:264-8.

45. Wagner H, Geyer B, Kiso Y, Hikino H, Rao GS. Coumestans as the main active principles of the liver drugs Eclipta alba and Wedelia calendulacea1. Plant Med 1986;52:370-4

46. Singh A, Duggal S, Suttee A, Singh J, Katekhaye S. Eclpita alba Linn.-ancient remedy with therapeutic potential. Int J Phytopharmacol 2010;1:57-63.

47. Jadhav VM, Thorat RM, Kadam VJ, Salaskar KP. Chemical composition, pharmacological activities of Eclipta alba. J Pharm Res 2002;2:1129-231.

48. Jain PK, Das DE. The wonder of herbs to treat-alopecia. Innov J Med Sci 2016;4:1-6.

49. Jadhav VM, Thorat RM, Kadam VJ, Sathe NS. Eclipta alba Linn Kesharaja: A review. J Pharm Res 2009;2:1236-41.

50. Bhansali S, Sharma A, Kumar A. Bhringraj (Eclipta alba (L.) Hassk): A medicinal plant of traditional value. Bioherald 2011;1:385969.

51. Chopra RN, Nayar SL, Chopra IC. Glossary of Indian Medicinal Plants. New Delhi: Council of Scientific and Industrial Research; 1956.

52. Shekokar S, Nayak SU. A Phytopharmacological review of prospective of Bhrungaraj (Eclipta alba Hassk.). Int J Ayurvedic Med 2017;8:1-7.

53. Feng L, Zhai YY, Xu J, Yao WF, Cao YD, Cheng FF, et al. A review on traditional uses, phytochemistry and pharmacology of Eclipta prostrata (L.) L. J Ethnopharmacol 2019;245:112109.

54. Sunita P, Mishra DN. Diagnostic parameters assisted with suitable photomicrographs, pharmacognostical and phytochemical study of Eclipta prostrata (L.) L. Glob J Res Med Plants Indig Med 2016;5:292.

55. Jayathirtha MG, Mishra SH. Preliminary immunomodulatory activities of methanol extracts of Eclipta alba and Centella asiatica. Phytomedicine 2004;11:361-5.

56. Mithun NM, Shashidhara S, Vivek Kumar R. Eclipta alba (L.) A review on its phytochemical and pharmacological profile. Pharmacologyonline 2011;1:345-57

57. Singh A, Singh A, Dwivedi V. Effect of Eclipta alba, Azadirachta indica, Pterocarpus marsupium, Tinospora cordifolia and Mangifera indica extracts on experimentally diabetic induced rats. Int J Sci Res 2017;6:1616-20.

58. Soni KK, Soni S. Eclipta alba (L.) an ethnomedicinal herb plant, traditionally use in Ayurveda. J Horticult 2017;4:1-4.

59. Sinha SH, Raghuwanshi RI. Phytochemical screening and antioxidant potential of Eclipta prostrata (L) La valuable herb. Int J Pharm Pharm Sci 2016;8:255-60.

60. Thenmozhi M, Jayanthi M. Phytochemical screening and antioxidant activity of Eclipta alba L. Asian J Pharm Clin Res 2019;12:215-8.

61. Singh B, Saxena AK, Chandan BK, Agarwal SG, Anand KK. In vivo hepatoprotective activity of active fraction from ethanolic extract of Eclipta alba leaves. Indian J Physiol Pharmacol 2001;45:435-41.

62. Saxena A, Gautam S, Arya KR, Singh RK. Comparative study of phytochemicals, antioxidative potential and activity of enzymatic antioxidants of Eclipta alba and Plumbago zeylanica by in vitro assays. Free Radic Antioxid 2016;6:139-44.

63. Latha BC, Ahalya S, Naidu PD, Mounica K, Kumar AR. Phytochemical evaluation of Andrographis paniculata, Cassia angustifolia and Eclipta alba. Indian J Res Pharm Biotechnol 2017;5:160-3.

64. Yahara S, Ding N, Nohara T, Masuda K, Ageta H. Taraxastane glycosides from Eclipta alba. Phytochemistry 1997;44:131-5.

65. Zhang JS, Guo QM. Studies on the chemical constituents of Eclipta prostrata (L). Yao xue xue bao Acta Pharm Sin 2001;36:34-7.

66. Kaushik-Basu N, Bopda-Waffo A, Talele TT, Basu A, Costa PR, Da Silva AJ, et al. Identification and characterization of coumestans as novel HCV NS5B polymerase inhibitors. Nucl Acids Res 2008;36:1482-96

67. Charpe TW, Rathod VK. Kinetics of ultrasound assisted extraction of wedelolactone from Eclipta alba. Braz J Chem Eng 2016;33:1003-10. 
68. Yuan HX, Zhao YL, Yan Y, Yu ZG. Studies on chemical constituents of herba ecliptae. Chin J Exp Tradit Med Form 2011;17:103-5.

69. Horn-Ross PL, Barnes S, Lee M, Coward L, Mandel JE, Koo J, et al. Assessing phytoestrogen exposure in epidemiologic studies: Development of a database (United States). Cancer Causes Control 2000;11:289-98.

70. Abdel-Kader MS, Bahler BD, Malone S, Werkhoven MC, van Troon F, David, et al. DNA-damaging steroidal alkaloids from Eclipta alba from the suriname rainforest. J Nat Prod 1998;61:1202-8.

71. Podolak I, Galanty A, Sobolewska D. Saponins as cytotoxic agents: A review. Phytochem Rev 2010;9:425-74.

72. Khanna VG, Kannabiran K. Anticancer-cytotoxic activity of saponins isolated from the leaves of Gymnema sylvestre and Eclipta prostrata on HeLa cells. Int J Green Pharm 2009;3:227-9.

73. Yildirim I, Kutlu T. Anticancer agents: Saponin and tannin. Int J Biol Chem 2015;9:332-40.

74. Kannabiran K. Antimicrobial activity of saponin fractions of the leaves of Gymnema sylvestre and Eclipta prostrata. World J Microbiol Biotechnol 2008;24:2737-40.

75. Han Y, Xia C, Cheng X, Xiang R, Liu H, Yan Q, et al. Preliminary studies on chemical constituents and pharmacological action of Eclipta prostrata L. Zhongguo Zhong Yao Za Zhi 1998;23:680-703.

76. Mehra PN, Nanda SS. Pharmacognosy of Bhringaraja. Antihepatotoxic drug of Indian origin. Ind J Pharm 1968;30:284

77. Kaur N, Chaudhary J, Jain A, Kishore L. Stigmasterol: A comprehensive review. Int J Pharm Sci Res 2011;2:2259.

78. Gomathy S, Narenderan ST, Meyyanathan SN, Gowramma B. Development and validation of HPLC method for the simultaneous estimation of apigenin and luteolin in commercial formulation. J Crict Rev 2020;7:2020.

79. Zhang M, Chen YY, Di XH, Liu M. Isolation and identification of ecliptasaponin D from Eclipta alba (L.) hassk. Yao Xue Xue Bao Acta Pharm Sin 1997;32:633-4

80. Upadhyay RK, Pandey MB, Jha RN, Pandey VB. Eclalbatin, a triterpene saponin from Eclipta alba. J Asian Nat Prod Res 2001;3:213-7.

81. Yahara S, Ding N, Nohara T. Oleanane glycosides from Eclipta alba. Chem Pharm Bull 1994;42:1336-8.

82. Jain S, Singh P. A dithienylacetylene ester from Eclipta-erecta Linn. Indian J Chem B Org Chem Include Med Chem 1988;27:99-100.

83. Lans C. Comparison of plants used for skin and stomach problems in Trinidad and Tobago with Asian ethnomedicine. J Ethnobiol Ethnomed 2007;3:1-2.

84. Verma RK, Singh HN, Thakur AK, Kohli SJ. Ethnobotanical survey of medicinal and aromatic plants of Bhagalpur Region. Int J Appl Sci Biotechnol 2020;8:216-22.

85. Sharma PV, Sharma G. Dhanvantari nighantu, Karveeradi varga, 4/10-11. $4^{\text {th }}$ ed. Varanasi: Chaukhamba Orientalia Publication; 2005. p. $122-23$.

86. Tripathi I. Raj Nighantu, Shatadvhadi Varga. $2^{\text {nd }}$ ed. Varanasi: Chaukhamda Krushnadasa Academy; 2006. p. 89.

87. Sharma PV, Sharma G. Kaiyadeva Nighantu, Oshadhi varga, 1/157375. $1^{\text {st }}$ ed. Varanasi: Chaukhamba Orientalia Publication; 1979. p. 637.

88. Muddgal D. Dravyagun Vijnana. $2^{\text {nd }}$ ed. Jaipur: Ayurvedic Hindi Pustak Bhandar; 2019.

89. Sharma P. Dravyagun Vigyan. Varanasi: Chaukambha Bharti Academy; 2019.

90. Gadi D, Bnouham M, Aziz M, Ziyyat A, Legssyer A, Legrand C, et al. Parsley extract inhibits in vitro and ex vivo platelet aggregation and prolongs bleeding time in rats. J Ethnopharmacol 2009; 125:170-4

91. Jadhav VM, Thorat RM, Kadam VJ, Gholve SB. Kesharaja: Hair vitalizing herbs. Int J PharmTech Res 2009;1:454-67.

92. Pathak AP, Misar S. Management of Khalitya (Hair Fall) by ayurvedic formulations-a review. Int Ayurveda Public 2017;2:675-80.

93. Pandey MK, Singh GN, Sharma RK, Lata S. Standardization of Yakrit Plihantak Churna: An ayurvedic polyherbal formulation. Int J Pharm Sci Res 2012;3:171.

94. Ladda PL, Magdum CS. Vitex negundo Linn.: Ethnobotany, phytochemistry and pharmacology a review. Int J Adv Pharm Biol Chem 2012;1:111-20.

95. Tewtrakul S, Subhadhirasakul S, Cheenpracha S, Karalai C. HIV-1 protease and HIV-1 integrase inhibitory substances from Eclipta prostrata. Phytother Res 2007;21:1092-5.

96. Boulos L, Hadidi MN, Gohary M. Weed flora of Egypt. Cairo, Egypt: American University in Cairo Press; 1984.

97. Dan NV, Nhu DT. Medicinal Plants in Vietnam. Manila: WHO Regional Office for the Western Pacific; 1990

98. Rai MB. Medicinal plants of Tehrathum district, Eastern Nepal. Our
Nat 2003;1:42-8.

99. Panthi MP, Singh AG. Ethnobotany of Arghakhanchi district, Nepal: Plants used in dermatological and cosmetic disorders. Int J Appl Sci Biotechnol 2013;1:27-32.

100.Khan AV, Khan AA. Ethnomedicinal uses of Eclipta prostrta Linn. Indian J Tradit Knowl 2008; 7:316-20.

101.Parkash V, Aggarwal A. Traditional uses of ethnomedicinal plants of lower foot-hills of Himachal Pradesh-I. Indian J Tradit Knowl 2010;9:319-21.

102.Pandey MK, Sharma RK, Lata S. Antibacterial activity of Eclipta alba (L.) Hassk. J Appl Pharm Sci 20111;1:14

103. Sardar AA, Khan Z, Perveen A, Zereen A. Appraisal of ethnobotanical uses of the wetland plants of Punjab, Pakistan. Afr J Tradit Complement Altern Med 2015;12:9-13.

104.Ali S, Shabbir A, Muhammad S. Ethnobotanical uses of some native and alien plants of The Jhok Reserve Forest, Punjab, Pakistan. Pak J Weed Sci Res 2018;24:89-103.

105.Anwer Z, Shabbir S, Iram T, Tariq S, Murad H. Ethnobotanical study of wild flora of Haroonabad, District Bahawalnagar, Punjab, Pakistan. Eur J Biol 2020;5:41-62.

106. Wariss HM, Ahmad S, Anjum S, Alam K. Ethnobotanical studies of dicotyledonous plants of Lal Suhanra national park, Bahawalpur, Pakistan. Int J Sci Res 2014;3:2452-60.

107.Kumar S, Das G, Shin HS, Kumar P, Patra JK. Diversity of plant species in the steel city of Odisha, India: Ethnobotany and implications for conservation of urban bio-resources. Braz Arch Biol Technol 2018;61:1-19

108.Ahmad M, Tripathi AK, Sharma JK. Ethnobotany of important medicinal plants growing as weed and their conservation. Perspect Biodivers India 2018;4:292-6.

109. Singh A, Singh PK. An ethnobotanical study of medicinal plants in Chandauli district of Uttar Pradesh, India. J Ethnopharmacol 2009; $121: 324-9$.

110. Thirumalai T, Beverly CD, Sathiyaraj K, Senthilkumar B, David E. Ethnobotanical study of anti-diabetic medicinal plants used by the local people in Javadhu hills Tamilnadu, India. Asian Pac J Trop Biomed 2012;2:S910-3.

111. Bhandari BS. Ethnobotanical plants used in health care and traditional practices by local inhabitants (Gujjars) of Rajaji Tiger Reserve, Uttarakhand, India. Indian J Tradit Knowl 2021;20:91-105.

112. Brinda R, Parvathy S. Ethnobotanical medicines of anaimalai union pollachi taluk, Coimbatore district, Tamilnadu. Anc Sci Life 2003;22:166

113.Das H, Chakraborty U. Ethnobotanical study of medicinal plants in the Dakshin Dinajpur district. Res Rev 2019;8:18-24.

114. Mahajan SK. Traditional herbal remedies among the tribes of Bijagarh of West Nimar district, Madhya Pradesh. Indian J Tradit Knowl 2005;6:375-7.

115. Hosamani PA, Lakshman HC, Kulkarni SS, Gadi S. Documentation of ethnobotanical medicinal plants growing in rock crevices of river Kali in Dandeli wild life Sanctuary. Life Sci Leaf 2012;3:36-9.

116. Vijayagiri RC, Mamidala E. Ethnobotanical investigations among traditional healers in Warangal district of Andhra Pradesh, India. Pharmacogn J 2012;4:13-7

117.Patil HM, Bhaskar VV. Medicinal uses of plants by tribal medicine men of Nandurbar district in Maharashtra. Explorer 2006;5:125-30.

118. Mali PR. Ethnobotanical studies of Peth and Trimbakeshwar district Nashik, Maharashtra, India. Trends Life Sci 2012;1:35-7.

119. Sudhakar P. Ethnobotanical studies in select parks of Chennai city. India J Environ Educ 2017; 17:1-33.

120.Ghatapanadi SR, Johnson N, Rajasab AH. Documentation of folk knowledge on medicinal plants of Gulbarga district, Karnataka. Indian J Tradit Knowl 2011;10:349-53.

121.Brishty SR, Setu NI, Anwar M, Jahan R, Mia MM, Kadir MF, et al. Ethnobotanical study on medicinal plants for dermatological disorders at Chittagong Hill Tracts, Bangladesh. Pharm Biomed Res 2020;6:61-90.

122. Rahman AH, Alam MS, Ahmad S, Naderuzzaman AT, Islam AK. An ethnobotanical portrait of a village: Koikuri, Dinajpur with reference to medicinal plants. Int J Biosci 2012;2:1-0.

123.Tudu D, Sinha VS. An ethnobotanical survey on medicinal plants used to mitigate anemia by tribes of east and West Singhbhum districts of Jharkhand, India. J Pharmacogn Phytochem 2017;6:2592-5.

124. Olatokunbo IS, Atinuke DA. Ethnobotanical survey of medicinal plants used by the indigenous people of Bayelsa state, Nigeria. Int J Eng Appl Sci Technol 2020;5:771-84.

125.de Boer HJ, Ichim MC, Newmaster SG. DNA barcoding and pharmacovigilance of herbal medicines. Drug Saf 2015;38:611-20. 
126.Grazina L, Amaral JS, Mafra I. Botanical origin authentication of dietary supplements by DNA-based approaches. Compr Rev Food Sci Food Saf 2020;19:1080-109.

127.Adewunmi CO, Ojewole JA. Safety of traditional medicines, complementary and alternative medicines in Africa. Afr $\mathrm{J}$ Tradit Complement Altern Med 2004;1:1-3.

128. Srirama R, Kumar JS, Seethapathy GS, Newmaster SG, Ragupathy S, Ganeshaiah KN, et al. Species adulteration in the herbal trade: Causes, consequences and mitigation. Drug Saf 2017;40:651-61.

129. Yee SK, Chu SS, Xu YM, Choo PL. Regulatory control of Chinese proprietary medicines in Singapore. Health Pol 2005;71:133-49.

130.Miller GM, Stripp R. A study of western pharmaceuticals contained within samples of Chinese herbal/patent medicines collected from New York City's Chinatown. Legal Med 2007;9:258-64.

131.Joharchi MR, Amiri MS. Taxonomic evaluation of misidentification of crude herbal drugs marketed in Iran. Avic J Phytomed 2012;2:105.

132.Ernst E, Coon JT. Heavy metals in traditional Chinese medicines: A systematic review. Clin Pharmacol Ther 2001;70:497-504.

133.Ernst E. Heavy metals in traditional Indian remedies. Eur J Clin Pharmacol 2002;57:891-6.

134.Ko RJ. Adulterants in Asian patent medicines. N Engl J Med 1998;339:847.

135.Obi E, Akunyili DN, Ekpo B, Orisakwe OE. Heavy metal hazards of Nigerian herbal remedies. Sci Total Environ 2006;369:35-41.

136. Caldas ED, Machado LL. Cadmium, mercury and lead in medicinal herbs in Brazil. Food Chem Toxicol 2004;42:599-603.

137.García-Rico L, Leyva-Perez J, Jara-Marini ME. Content and daily intake of copper, zinc, lead, cadmium, and mercury from dietary supplements in Mexico. Food Chem Toxicol 2007;45:1599-605.

138.Ernst E. Adulteration of Chinese herbal medicines with synthetic drugs: A systematic review. J Intern Med 2002;252:107-13.

139. Walker KM, Applequist WL. Adulteration of selected unprocessed botanicals in the US retail herbal trade. Econ Bot 2012;66:321-7.

140. Yadav P, Mahour K, Kumar A. Standardization and evaluation of herbal drug formulations. J Adv Lab Res Biol 2011;2:161-6.

141.Posadzki P, Watson L, Ernst E. Contamination and adulteration of herbal medicinal products (HMPs): An overview of systematic reviews. Eur J Clin Pharmacol 2013;69:295-307.

142.Sagar BP, Zafar R, Panwar R, Kumar V, Mangla A. Herbal drugs standardization. Indian Pharm 2005;4:19-22.

143. Chen S, Yao H, Han J, Liu C, Song J, Shi L, et al. Validation of the ITS2 region as a novel DNA barcode for identifying medicinal plant species. PLoS One 2010;5:e8613.

144.Singh B, Saxena AK, Chandan BK, Agarwal SG, Bhatia MS, Anand KK. Hepatoprotective effect of ethanolic extract of Eclipta alba on experimental liver damage in rats and mice. Phytother Res 1993; $7: 154-8$

145.Naik KS, Gurushanthaiah M, Kavimani M, Prabhu K, Lokanadham S. Hepatoprotective role of Eclipta alba against high fatty diet treated experimental models a histopathological study. Maedica 2018;13:217.

146. Ahirwar DK, Saxena RC. Hepatoprotective activity of ethanolic extract of Eclipta alba in albino rats. Biomed Pharmacol J 2008;1:235.

147.Kumar K, Katiyar AK, Swamy M, Sahni YP, Kumar S. Hepatoprotective effect of Eclipta alba on experimentally induced liver damage in rats. Indian J Vet Pathol 2013;37:159-63.

148.Indhuleka A, Jeyaraj M. Hepatoprotective effect of Eclipta alba on membrane marker enzymes against paracetamol induced liver damage. Orient J Chem 2019;35:1215

149.Begum S, Lee MR, Gu LJ, Hossain M, Kim HK, Sung CK. Comparative hair restorer efficacy of medicinal herb on nude (Foxn) mice. Biomed Res Int 2014;14:1-9.

150.Chaudhary H, Dhuna V, Singh J, Kamboj SS, Seshadri S. Evaluation of hydro-alcoholic extract of Eclipta alba for its anticancer potential: An in vitro study. J Ethnopharmacol 2011;136:363-7.

151.Gurrapu S, Mamidala E. In vitro antibacterial activity of alkaloids isolated from leaves of Eclipta alba against human pathogenic bacteria. Pharmacogn J 2017:9:573-7.

152.Karthikumar S, Vigneswari K, Jegatheesan K. Screening of antibacterial and antioxidant activities of leaves of Eclipta prostrata (L). Sci Res Essay 2007;2:101-4.

153. Manvar D, Mishra M, Kumar S, Pandey VN. Identification and evaluation of anti hepatitis C virus phytochemicals from Eclipta alba. J Ethnopharmacol 2012;144:545-54

154.Banji O, Banji D, Annamalai AR, Manavalan R. Investigation on the effect of Eclipta alba on animal models of learning and memory. Indian J Physiol Pharmacol 2007;51:274.

155.Syed SD, Deepak M, Yogisha S, ChandrashekarAP, Muddarachappa KA, D'Souza P, et al. Trypsin inhibitory effect of wedelolactone and demethylwedelolactone. Phytother Res 2003;17:420-1.

156. Chanu TI, Roy SD, Chadha NK, Rawat KD, Sharma A, Kumar K. Antistress ability of Eclipta alba ethanol extract in Labeo calbasu fingerlings exposed to acid stress. Isr J Aquac Bamidegh 2013;65:1-9. 